\title{
PERANCANGAN MODUL PEMBELAJARAN HURUF BRAILLE BERBASIS MIKROKONTROLER UNTUK MEMBANTU PROSES BELAJAR DISABILITAS NETRA
}

\author{
I Putu Agus Padma Diana ${ }^{1}$, I Gusti Agung Putu Raka Agung ${ }^{2}$, Pratolo Rahardjo ${ }^{3}$ \\ ${ }^{1,2,3}$ Jurusan Teknik Elektro, Fakultas Teknik, Universitas Udayana \\ Email: iputuaguspadmadiana@gmail.com ${ }^{1}$, igapraka@yahoo.co.id ${ }^{2}$, pratolo@unud.ac.id ${ }^{3}$
}

\begin{abstract}
Abstrak
Kami merancang modul pembelajaran huruf Braille berbasis mikrokontroler sebagai alat bantu proses pembelajaran huruf Braille penyandang disabilitas netra. System oprasi utama yang digunakan adalah Arduino ATMega 2560 sebagai pengolah data input dan meberikan perintah output sesai perencanaan. Hasil penelitian ini berupa sebuah sistem yang terdiri dari Keyboard dengan push button sebagai input data, DFPlayer mini sebagai output suara dan LCD untuk menampilkan karakter Input/output. Modul pembelajaran huruf Braille dapat digunakan selama 5,6 jam dalam kondisi modul keyboard tanpa ditekan (stand by) dan 5,04 jam dalam kondisi modul keyboard ditekan dengan volume DFPlayer mini minimum atau maksimum.
\end{abstract}

Kata kunci: Disabilitas Netra, Arduino ATMega 2560, DFPlayer Mini

\section{Abstract}

We design Braille-learning module based on microcontroller as a helping tool for Braille-learning process for people with vision disabillity. The main operating system used is Arduino ATMega 2560 as the input data processor and provide output commands according to planning. The result is a system consists of a push-button Keyboard for data input, DFPlayer mini for sound output and a $L C D$ for character display. Braille-learning module can be used for 5.6 hours under standby keyboard module condtion and 5.04 hours in keyboard module condition suppressed with minimum or maximum mini DFPlayer volume.

Keywords: Vision Disability, Arduino ATMega 2560, Mini DFPlayer

\section{PENDAHULUAN}

Undang-Undang (UU No.4 Tahun 1997) tentang Penyandang Cacat pasal 1 ayat 1 menyatakan bahwa penyandang cacat dapat terbagi menjadi tiga, antara lain cacat fisik, cacat mental serta cacat fisik dan mental [1].Salah satu penyandang cacat yang menjadi perhatian khusus pada penelitian ini ialah disabilitas netra yang termasuk ke dalam penyandang cacat fisik di Panti Dria Raba, Denpasar. Keterbatsan yang dimiliki menyebabkan sebagian orang yang menyandang disabilitas netra tidak dapat merasakan pendidikan yang layak seperti orang lain pada umumnya. Kurangnya fasilitas yang mendukung untuk para pengajar disekolah tersebut dalam proses pengajaran siswanya untuk membaca huruf Braille, menyebabkan sang pengajar sulit untuk mengajarkan membaca huruf Braille, ditambah lagi siswa yang diajar memiliki kemampuan dalam mengingat huruf Braille yang sulit, sehingga sang pengajar harus mengulangi kata yang sama berkali-kali. Penelitian yang dilakukan oleh Muktafin dkk [2], Asa Nanda dkk [3], dan Syahrul [4] yang masih memiliki beberapa kekurangan sererti sulitnya booting pada program PC yang digunakan, kurangnya efisiensi dan fleksibilitas dari yang telah dibuat,sehingga penulis ingin mengajukan sebuah penelitan dengan mendesain ulang alat bantu pembelajaran huruf Braille berbasis mikrokontroler yang dapat mempersingkat waktu penggunaan, serta alat yang dibuat lebih efisien dan fleksibel dari alat-alat yang sudah ada pada penelitian sebelumnya. 
Sebuah alat yang akan dirancang pada penelitian ini menggunakan mikrokontroler arduino mega 2560, dikarenakan mempermudah pada proses pemrograman serta berfungsi sebagai kendali utama. Input arduino berasal dari keyboard yang berbentuk simbol huruf Braille berjumlah 42 buah push button Mikrokontroler akan mengolah masukan dan keluaran menjadi suara dan tampilan pada LCD. Suara yang dihasilkan oleh DFPlayer mini sama dengan tampilan huruf, angka, dan tanda baca pada LCD. Jika orang dengan disabilitas netra menggunakan keyboard maka akan ditampilkan text dan suara dari tombol keyboard yang ditekan tersebut.

Rumusan masalah pada penelitian ini adalah bagaimana perancangan modul pembelajaran huruf Braille berbasis arduino ATMega 2560 untuk membantu proses belajar huruf Braille disabilitas netra?

Tujuan penelitian ini adalah merancang modul pembelajaran huruf Braille berbasis arduino ATMega 2560 untuk membantu proses belajar huruf Braille disabilitas netra.

\section{KAJIAN PUSTAKA}

Huruf Braille memiliki kombinasi enam buah titik timbul yang digunakan untuk mempermudah penderita tuna netra dalam sistem pembacaan huruf Braille. Dengan metode ini dapat mempermudah para penderita tuna netra untuk membaca huruf Braille, dikarenakan cara membaca dengan meraba titik - titik tonjolan huruf Braille. Penemu sistem tersebut adalah Louis Braille pada tahun 1827 yang menciptakan format tulisan yang disebut tulisan Braille [4]. Gambar 1 menunjukkan susunan huruf Braille yang terdiri dari kombinasi maksimal enam buah lokasi titik.

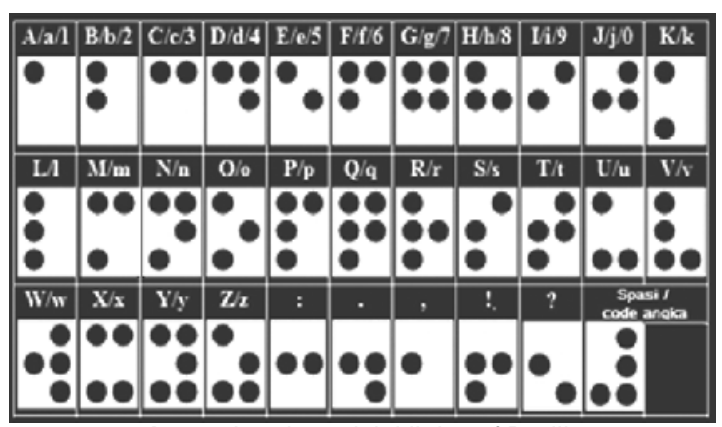

Gambar 1. Letak posisi titik huruf Braille

LCD (Liquid Crystal Display)
LCD (Liquid Crystal Display) dapat digunakan sebagai tampilan dari hasil pengolahan program pada suatu sistem, termasuk pada hasil dari output pengolahan data padaArduino ATMega 2560 yang digunakan sebagai prosesor.

Arduino Mega

Arduino Mega adalah sebuah board yang menggunakan mikrokontroler berbasis ATMega 2560 dimana board tersebut memiliki 15 pin analog input, 10 pin communication, 32 pin Input/Output (I/O) dan 12 pin PWM.

\section{DFPlayer Mini}

DFPlayer Mini adalah sebuah modul micro SD dimana modul tersebut dapat mengases dan menyimpan data pada micro SD.

\section{Loudspeaker}

Loudspeaker adalah komponen yang dapat mengubah tegangan listrik (sinyal audio) menjadi gelombang suara dimana listrik akan mengaliri kumparan induktor yang ada dibelakang membran loundspeaker maka akan menggerakan karet membran sesuai dengan polaritas tegangan dan kuat arus yang diperoleh oleh kumparan inductor.

\section{I2C Protokol}

I2C berkomunikasi dengan perangkat lain menggunakan pin SDA dan pin SCL, berbeda dengan menggunakan Chip mikrokontroler ATmega328 yang berkomunikasi melalui pin MOSI, MISO, SCK, reset, VCC dan GND [5].

\section{Arduino IDE}

Arduino IDE adalah software Arduino IDE proses compile dan upload program dapat dilakukan dengan meggunakan bahasa program $\mathrm{C}$, dengan diconfilenya program dapat diproses pada sistem mikrokontroler Arduino ATMega 2560.

\section{METODE PERANCANGAN}

Metode perancangan blok diagram sistem, dilakukan perancangan blok secara umum agar dapat mempermudah dalam tahap perancangan dan pembuatan setiap blok hardware dan software yang sudah direncanakan.Kemudian lanjutkan dengan proses perancangan perangkat 
keras yang meliputi setiap bagian dari rangkaian penyusun blok diagram. Tahap berikutnya adalah perakitan bagian - bagian rangkaian dan dilanjutkan dengan sebuah proses perancangan perangkat lunak untuk beberapa bagian dari rangkaian yang membutuhkan program agar dapat bekerja dalam tahap pengujian yang merupakan tahap untuk menguji kinerja rangkaian -rangkaian (hardware) dan program (software) apakah sudah sesuai dengan yang direncanakan. Tahap terakhir yakni pengujian secara keseluruhan dari sistem yang telah dirancang untuk mengetahui kinerja pada sistem secara keseluruhan. Diagram alir perancangan dapat dilihat pada Gambar 2.

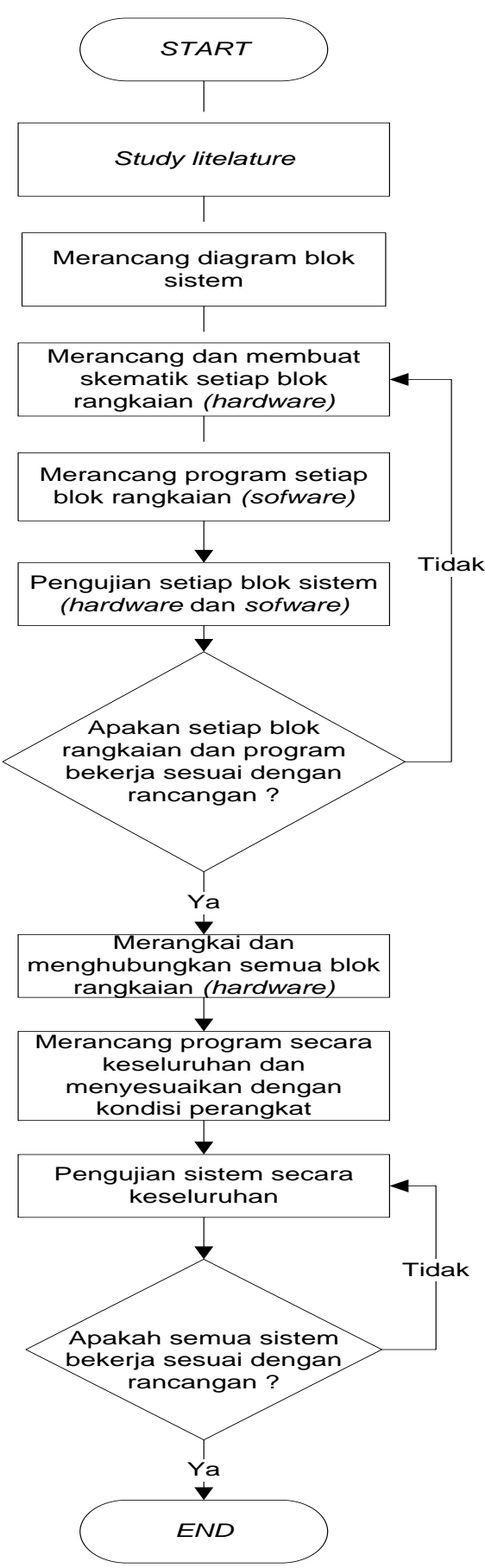

Gambar 2. Diagram alir perancangan modul pembelajaran huruf Braille berbasis mikrokontroler untuk membantu proses pembelajaran disabilitas netra

4. HASIL DAN PEMBAHASAN

4.1 Realisasi Hasil Perancangan Modul Pembelajaran Huruf Braille

Gambar 3 memperlihatkan hasil dari alat yang telah direalisasikan. 


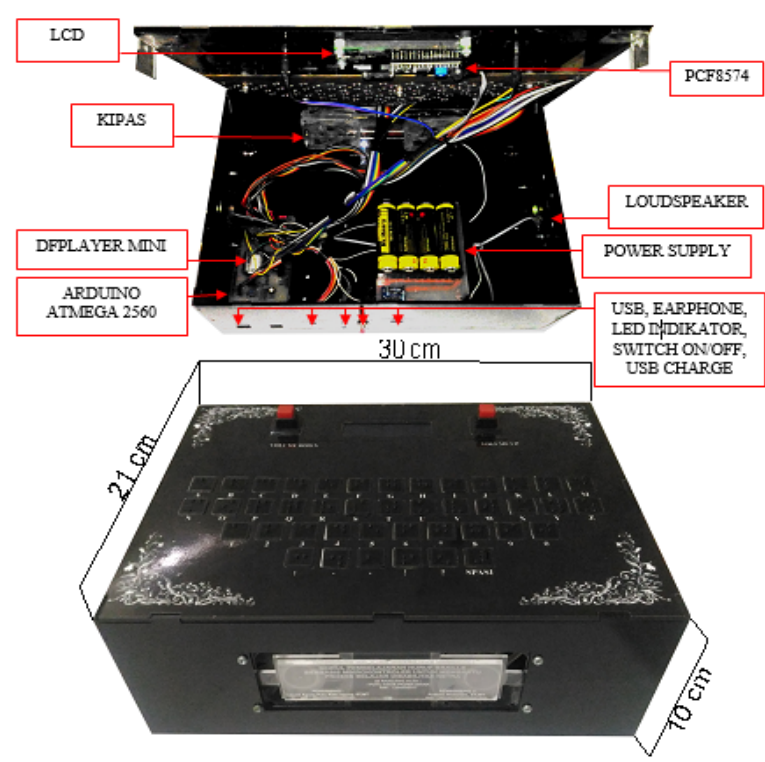

Gambar 3. Realisasi perancangan modul pembelajaran huruf Braille berbasis mikrokontroler untuk membantu proses belajar disabilitas netra

Modul pembelajaran huruf Braille memiliki spesifikasi antara lain tinggi modul $30 \mathrm{~cm}$, panjang modul $10 \mathrm{~cm}$, lebar modul $21 \mathrm{~cm}$, berat keseluruhan modul yakni 942 gram, catu daya (charger baterai) yang digunakan 5 volt , 2 ampere, dan power supplay 4 baterai 4,2 volt, 1,2 ampere perbaterai.

\subsection{Pengujian dan Pembahasan Modul Pembelajaran Huruf Braille}

Adapun perangkat yang akan diuji adalah sebagai berikut:

\subsubsection{Pengujian dan Pembahasan Arduino ATMega 2560 dengan rangkaian LCD}

Gambar 4 menunjukan blok diagram pengujian Arduino ATMega 2560 terhadap IC PCF8574 dan LCD.

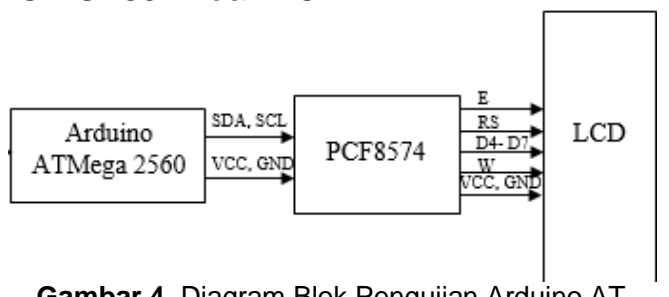

Gambar 4. Diagram Blok Pengujian Arduino AT Mega 2560 terhadap IC PCF8574 dan LCD

Pengujianbertujuan untuk mengetahui pin I2C dari Arduino ATMega 2560 terhadap IC PCF8574 dan LCD sudah bisa bekerja dengan baik. Software yang digunakan pada proses pengujian adalah
Software Arduino 1.6.4. Digunakan LCD sebagai media untuk menampilkan display karakter tulisan. Apabila karakter alphanumeric pada LCD berhasil ditampilkan, maka Arduino ATMega 2560 dinyatakan berfungsi denganbaik.Hasil pengujian dari penelitian dapat dilhat pada Gambar 5.

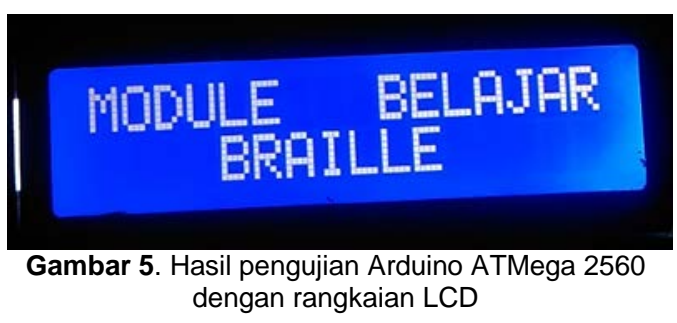

\subsubsection{Pengujian dan Pembahasan Rangkaian Input Keyboard}

Pengujiandanpembahasan rangkaian Input Keyboard bertujuan untuk menguji nilai output pada setiap pin push button yang akan digunakan sebagai input dari sebuah sistem perancangan modul pembelajaran huruf Braille untuk memastikan tegangan input yang diberikan oleh Keyboard. Pada Gambar 5 menunjukan blok diagram pengujian Keyboard.

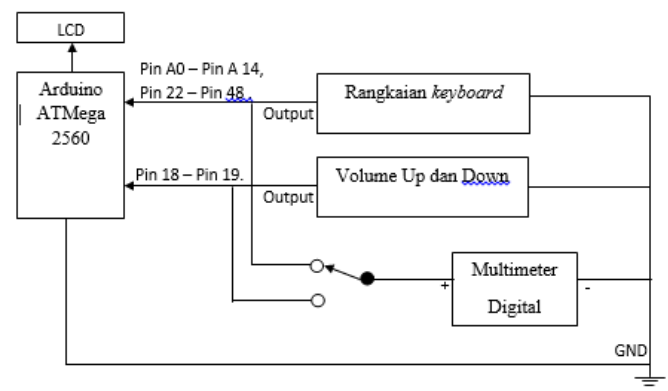

Gambar 6. Diagram Blok Pengujian Keyboard

Berdasarkan diagram blok pada Gambar 6 pengujian dilakukan dengan menggunakan multimeter digital untuk melakukan pengukuran tegangan pada setiap pin output pada Keyboard yang berjumlah 42 pin untuk push button huruf, angka,dan tanda baca serta 2 pin tambahan untuk volume. Hasil pengujian dapat dilihat pada Gambar 7 sampai dengan 9. 


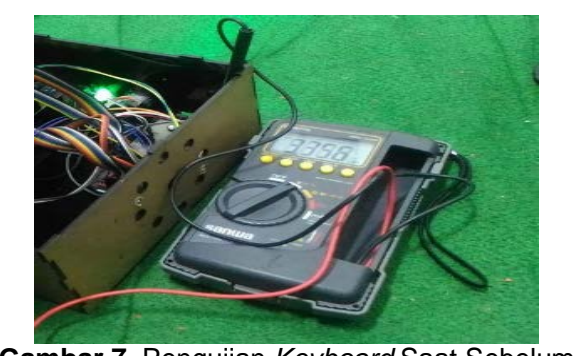

Gambar 7. Pengujian Keyboard Saat Sebelum Ditekan
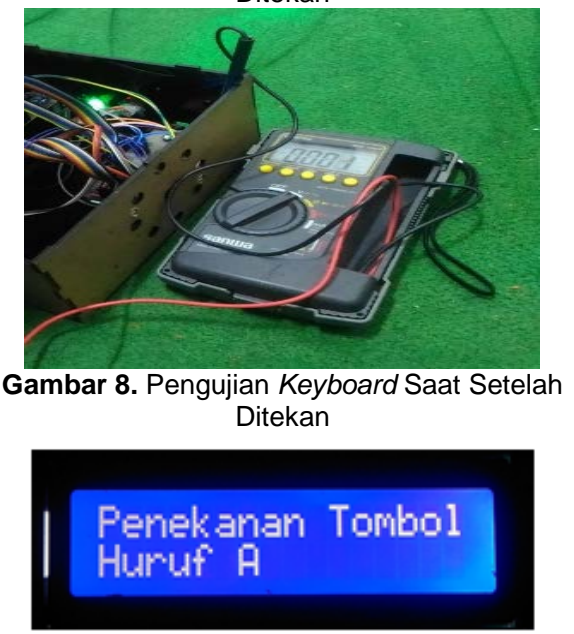

Gambar 9. Contoh Tampilan Pada LCD Pada Saat tombol Keyboard Ditekan

Table 1 dapat dilihat hasil pengujian pin Keyboard secara keseluruhan.

Tabel 1. Hasil pengujian rangkaian input Keyboard

\begin{tabular}{|c|c|c|c|c|}
\hline \multirow{2}{*}{ No } & \multirow{2}{*}{ Pin } & \multicolumn{2}{|c|}{ Nitai Tegangan } & \multirow{2}{*}{ Tampilan LCD } \\
\hline & & Setelgh diteksn & Sebelum diteknu & \\
\hline 1 & $\operatorname{Pin} 22$ & $0,01 \mathrm{~V}$ & $3,35 \mathrm{~V}$ & Heruf $A$ \\
\hline 2 & Pin 23 & $0,00 \mathrm{~V}$ & $3,35 \mathrm{~V}$ & Amurf $\overline{3}$ \\
\hline 3 & Pin 24 & $0,01 \mathrm{~V}$ & $3,3+\mathrm{V}$ & huruf C \\
\hline 4 & Pin 2 & $0,00 \mathrm{~V}$ & $3,35 \mathrm{~V}$ & Hinuf D \\
\hline 3 & $\operatorname{Pin} 16$ & $0,01 \mathrm{~V}$ & $3,36 \mathrm{~V}$ & Hunde E \\
\hline 6 & $\sin 2 \pi$ & $0,01 \mathrm{~V}$ & $3,36 \mathrm{~V}$ & Hurer $F$ \\
\hline 7 & Pin 25 & $0,00 \mathrm{~V}$ & $3,35 \mathrm{~V}$ & Haruf 6 \\
\hline 8 & $\operatorname{Pin} 29$ & $0,01 \mathrm{~V}$ & $3,3+\mathrm{V}$ & Hinuf $\mathrm{H}$ \\
\hline 9 & Pin $30^{\circ}$ & $0,01 \mathrm{~V}$ & $3,3+\mathrm{V}$ & Henf 1 \\
\hline 10 & Pin 31 & $0,01 \mathrm{~V}$ & $3,35 \mathrm{~V}$ & Hienuf J \\
\hline 11 & Pin 32 & $0,00 \mathrm{~V}$ & $3,35 \mathrm{~V}$ & Finuf $\mathrm{K}$ \\
\hline 12 & Pin 33 & $0,00 \mathrm{~V}$ & $3,35 \mathrm{~V}$ & Furne L \\
\hline 13 & Pin 34 & $0,01 \mathrm{~V}$ & $3,36 \mathrm{~V}$ & Hurut $M$ \\
\hline 14 & $\operatorname{Pin} 35$ & $0,01 \mathrm{~V}$ & $3,35 \mathrm{~V}$ & Finuf $N$ \\
\hline 15 & $\operatorname{Pin} 36$ & $0,01 \mathrm{~V}$ & $3,3+\mathrm{V}$ & Hinufo \\
\hline 16 & Pin 37 & $0,00 \mathrm{~V}$ & $3,35 \mathrm{~V}$ & Hurnef ? \\
\hline 17 & Pin 35 & $0,01 \mathrm{~V}$ & $3,33 \mathrm{~V}$ & Hiruf Q \\
\hline 13 & Pin 39 & $0,00 \mathrm{~V}$ & $3,35 \mathrm{~V}$ & himuf $\bar{k}$ \\
\hline 19 & Pin 40 & $0,00 \mathrm{~V}$ & $3,35 \mathrm{~V}$ & Hurnef 3 \\
\hline 20 & Pin 41 & $0,00 \mathrm{~V}$ & $3,35 \mathrm{~V}$ & Hurut $T$ \\
\hline 21 & Pin 42 & $0,00 \mathrm{~V}$ & $3,35 \mathrm{~V}$ & Hinuf U \\
\hline 22 & Pin 43 & $0,00 \mathrm{~V}$ & $3,35 \mathrm{~V}$ & Heruf V \\
\hline 23 & Pin 44 & $0,00 \mathrm{~V}$ & $3,35 \mathrm{~V}$ & Hiruf W \\
\hline 24 & Pin 45 & $0,00 \mathrm{~V}$ & $3,35 \mathrm{~V}$ & Hinuf $X$ \\
\hline 25 & Pin 45 & $0,00 \mathrm{~V}$ & $3,35 \mathrm{~V}$ & Finuf $Y$ \\
\hline 26 & Pin 47 & $0,00 \mathrm{~V}$ & $3,35 \mathrm{~V}$ & Finut $\mathrm{Z}$ \\
\hline 27 & Pin $A^{0}$ & $0,01 \mathrm{~V}$ & $3,36 \mathrm{~V}$ & Angla 1 \\
\hline 25 & Pin $A I$ & $0,01 \mathrm{~V}$ & $3,35 \mathrm{~V}$ & Angle 2 \\
\hline 29 & Pin $A 2$ & $0,01 \mathrm{~V}$ & $3,35 \mathrm{~V}$ & Angea 3 \\
\hline 30 & Pin $A 3$ & $0,00 \mathrm{~V}$ & $3,35 \mathrm{~V}$ & Angla 4 \\
\hline 31 & Pin $A 4$ & $0,00 \mathrm{~V}$ & $3,35 \mathrm{~V}$ & Anglas 5 \\
\hline 32 & Pin $A^{5}$ & $0,00 \mathrm{~V}$ & $3,35 \mathrm{~V}$ & Angla 6 \\
\hline 33 & Pin $A 6$ & $0,00 \mathrm{~V}$ & $3,35 \mathrm{~V}$ & Angla ? \\
\hline 34 & Pin $A 7$ & $0,00 \mathrm{~V}$ & $3,35 \mathrm{~V}$ & Angle 8 \\
\hline 35 & Pin $A S$ & $0,00 \mathrm{~V}$ & $3,35 \mathrm{~V}$ & Angea 9 \\
\hline 36 & Pin 19 & $0,00 \mathrm{~V}$ & $3,35 \mathrm{~V}$ & Anglea 0 \\
\hline 37 & Pin $A 10$ & $0,00 \mathrm{~V}$ & $3,35 \mathrm{~V}$ & tansa tiflk \\
\hline 35 & Pin AII & $0,00 \mathrm{~V}$ & $3,3+\mathrm{V}$ & tanda boma \\
\hline 39 & Pin $A 12$ & $0,00 \mathrm{~V}$ & $3,3+\mathrm{V}$ & trandas sera \\
\hline 40 & Pin $A 13$ & $0,00 \mathrm{~V}$ & $3,35 \mathrm{~V}$ & $\operatorname{tansin}+2 m y 2$ \\
\hline 41 & Pin II $^{4}$ & $0,01 \mathrm{~V}$ & $3,33 \mathrm{~V}$ & tanda taik disas \\
\hline 42 & Pin 45 & $0,00 \mathrm{~V}$ & $3,35 \mathrm{~V}$ & Fpsi \\
\hline 43 & Pin 18 & $0,01 \mathrm{~V}$ & $3,36 \mathrm{~V}$ & - \\
\hline 44 & Pin 19 & $0,00 \mathrm{~V}$ & $3,35 \mathrm{~V}$ & - \\
\hline
\end{tabular}

\subsubsection{Pengujian dan Pembahasan} Rangkaian DFPlayer Mini

Pengujiandanpembahasan rangkaian DFPlayer mini bertujuan untuk menguji akurasi dari pembacaan data yang telah disimpan pada microSD. DFPlayer Mini akan membaca data yang disimpan pada microSD sesuai dengan inputan yang diberikan oleh Arduino. Data yang dibaca DFPlayer Mini pada microSD akan dikonversi menjadi sinyal audio dan dilanjutkan ke loundspeaker untuk dikonversi menjadi suara. Gambar 10 menunjukan diagram blok pengujian rangkaian DFPlayer Mini

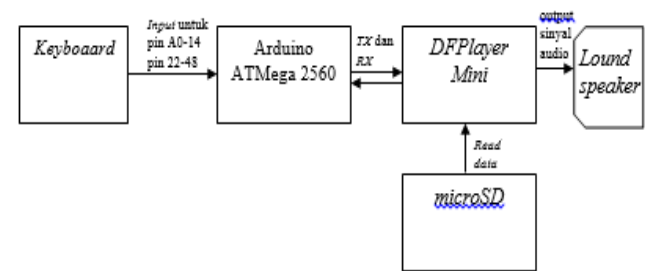

Gambar 10. Diagram Blok Pengujian Rangkaian DFPlayer Mini

Pengujian bertujuan untuk mengetahui apakah DFPlayer Mini bisa mengeluarkan suara sesuai dengan data yang tersimpan pada microSD dimana 
data suara berupa alphabet, angaka, tanda baca, volume dan kalimat pembukaan modul pembelajaran huruf Braille. Suara yang dihasilkan oleh DFPlayer Mini dipengaruhi oleh printah pada Arduino ATMega 2560 dan input Keyboard.

\subsubsection{PengujiandanPembahasan \\ Rangkaian Secara Keseluruhan \\ Terdapat 4 komponen utama pada} sistem yang memiliki keterkaitan dan saling mempengaruhi. Komponen utama tersebut terdiri dari Keyboard, Arduino ATMega 2560, DFPlayer mini, dan terakhir LCD. Pengujian ini juga bertujuan untuk mengetahui konsumsi daya listrik yang digunakan oleh modul huruf Braille apabila dioperasikan. Adapun beberapa pengujian yang akan dilakukan yakni:

A. Pengujian dan pembahasan input Keyboard dengan output data yang ditampilkan oleh LCD dan suara yang dihasilkan oleh DFPlayer mini.

Pada pengujian ini bertujuan untuk mengetahui hasil dari sinkronisasi dari data input dengan output yang dihasilkan, apakah sudah sesuai dengan symbol dari huruf,angka, dan tanda baca yang ditekan pada Keyboard. Dimana dengan menekan pushbutton pada Keyboard secara berurutan akan diketahui pin pada Arduino yang mendapatkan kondisi low atau logika 0 . Dengan mengetahui kondisi setiap pin pada Arduino maka diketahui output yang akan data ditampilkan pada LCD dan suara pada DFPlayer mini, sesuai dengan susunan program yang telah dibuat dan ditanamkan pada Arduino ATMega 2560 sesuai dengan rancangan yang telah direncanakan sebelumnya.

B. Pengujian dan pembahasan konsumsi energi listrik yang digunakan oleh modul huruf Braille

Pengujian konsumsi energi dapat dibagi menjadi 3 bagian pengujian yakni pengujian modul Keyboard tanpa ditekan, pengujianmodul Keyboard ditekan dengan volume DFPlayer mini volume minimum, dan pengujian modul Keyboard ditekan dengan volume DFPlayer mini volume maksimum.

Blok diagram pada Gambar 11 menunjukkan cara pengujian daya dengan mengukur arus dan tegangan terlebih dahulu dengan menjamper alat ukur diantara power supplay dengan rangkaian beban pada modul. Power supplay yang disediakan adalah 4 buah baterai yang tersusun paralel dengan tegangan 4,2 Volt dan arus 1,2 Ampere perbaterai. Alat tidak dapat digunakan lagi apabila tegangan pada power supplay di bawah 3,2 Volt. Diagram blok pengujian dapat dilihat pada Gambar 11.

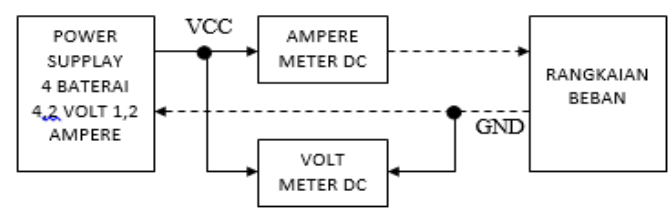

Gambar 11. Diagram blok pengujian konsumsi energi listrik

Baterai tersusun secara paralel tegangan baterai tetap sebesar 4,2 Volt

$I_{\text {total }}=I_{\text {bat1 }+} I_{\text {bat2 }}+I_{\text {bat3 }}+I_{\text {bat4 }}$ jadi $I_{\text {total }}=1,2+$ $1,2+1,2+1,2=4,8$ Ampere.

Energi tersimpan pada baterai adalah sebagai berikut :

$W=V \times I \times T \quad($ Ket : $W=$ Energi listrik, $V$ = Tegangan, $I=$ Arus, $T=$ Waktu)

$W=4,2$ Volt $\times 1,2$ Ampere $\times 1$ hour

$W=5,04$ Watt hour

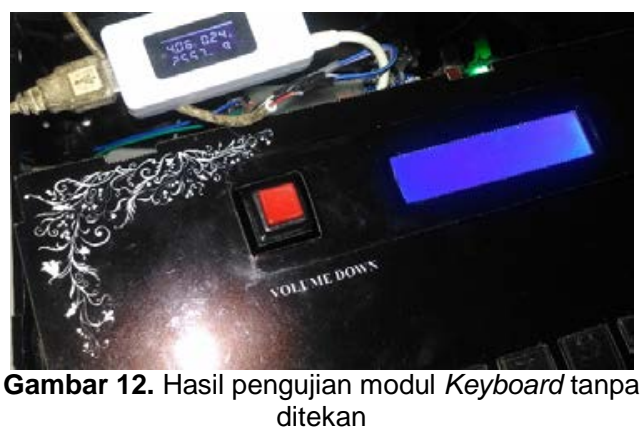

Pengujian pada Gambar 12 dilakukan selama 1 jam maka didapatkan hasil data tegangan 4,06 volt DC dan arus 0,24 ampere. Sehingga dapat dihitung konsumsi energy ketika modul Keyboard tanpa ditekan sebagai berikut.

$\mathrm{W}=\mathrm{V} \times \mathrm{I} \times \mathrm{T} \quad$ (Ket : $\mathrm{W}=$ Energi listrik, $\mathrm{V}$ = Tegangan, $\mathrm{I}=$ Arus, $\mathrm{T}=$ Waktu)

$W=4,06 \mathrm{~V} \times 0,24 \mathrm{~A} \times 1 \mathrm{H}=0,9$ Watt Hour 


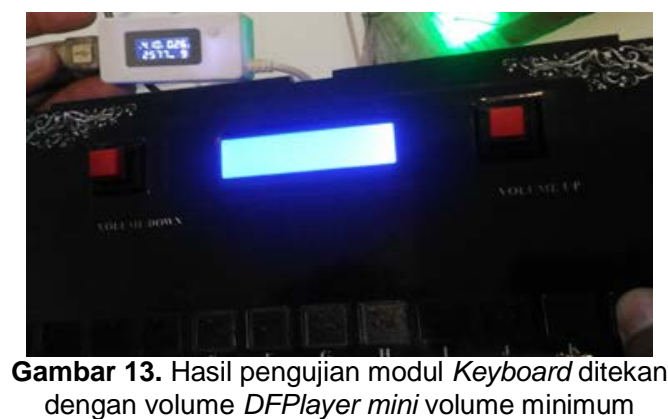

Pengujian pada Gambar 13 dilakukan selama 1 jam dengan data yang diperoleh adalah tegangan 4,10 volt DC dan arus 0,26 ampere. Sehingga dapat dihitung konsumsi energi ketika modul Keyboard ditekan dengan volume DFPlayer mini volume minimum sebagai berikut.

$W=V \times I \times T \quad($ Ket : $W=$ Energi listrik, $V$ = Tegangan, $I=$ Arus, $T=$ Waktu)

$W=4,10 \mathrm{~V} \times 0,26 \mathrm{~A} \times 1 \mathrm{H}=1$ Watt Hour

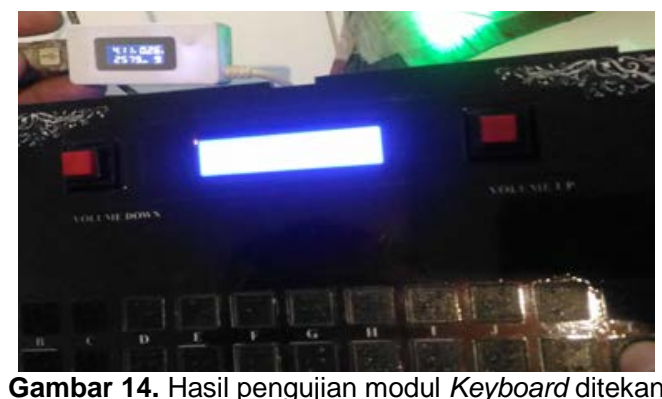

Pengujian pada Gambar 14 dilakukan selama 1 jam maka didapatkan data tegangan 4,11 volt DC dan arus 0,26 ampere. Sehingga dapat dihitung konsumsi energi ketika modul Keyboard ditekan dengan volume DFPlayer mini volume maksimum sebagai berikut.

$W=V \times I \times T \quad($ Ket : $W=$ Energi listrik, $V$ $=$ Tegangan, $I=$ Arus, $T=$ Waktu)

$W=4,11 \mathrm{~V} \times 0,26 \mathrm{~A} \times 1 \mathrm{H}=1$ Watt Hour

\section{KESIMPULAN}

1) Input data push button pada Keyboard yang telah ditekan dengan output suara yang dihasilkan oleh DFPlayer mini, serta tampilan karakter yang ditampilkan oleh LCD sudah sesuai dengan perencanaan.
2) Modul pembelajaran huruf Braille dapat digunakan selama 5,6 jam dalam kondisi modul Keyboard tanpa ditekan (stand by). Apabila modul pembelajaran huruf Braille digunakan dalam kondisi modul Keyboard ditekan dengan volume DFPlayer mini minimum atau maksimum, modul dapat digunakan selama 5,04 jam.

\section{DAFTAR PUSTAKA}

[1] Undang - Undang Negara Republik Indonesia. UU Negara Republik Indonesia Nomor 4 Tahun 1997 Tentang Penyandang Cacat. 2017. Jakarta

[2] Muktafin, Elik Hari dan Luthfi, Emha Taufiq. Perancangan Aplikasi Media Komunikasi Penyandang Tunanetra Btouch Dengan Virtual Braille Keyboard Berbasis Android.2015. Naskah Publikasi. Sekolah Tinggi Manajemen Informatika dan Komputer Amikom Yogyakarta

[3] Nanda, Ardhian Satrio Adi., Anisa, Marselia., dan Mulatsih, Winahyu Tri. Keyboard Braille Dengan Output Suara Sebagai Alat Pembelajaran Untuk Penyandang Tunanetra.2014.Skripsi. Politeknik Negeri Malang Teknik Elektro Malang.

[4] Syahrul dan Chaerudin. Pengembangan Alat Bantu Baca Bagi Tunanetra Berbasis Jaringan Komputer. 2011. Jurnal Teknik Komputer, 19 (1), h: 37-49.

.[5] Suardiana, I Made Nova., I Gusti Agung Putu Raka Agung., dan Pratolo Rahardjo. Rancang Bangun Sistem Pembacaan Jumlah Konsumsi Air Pelanggan PDAM Berbasis Mikrokontroler Atmega328 Dilengkapi SMS. 2017. Teknologi Elektro, 16 (1), h: 31-40

[6] Sinaulan, Olivia M., Rindengan, Yaulie D. Y., dan Sugiarso, Brave A. 2015. Perancangan Alat Ukur Pengukut Kecepatan Kendaraan 
Menggunakan ATMega 16. EJournal Teknik Elektro dan Komputer, ISSN : 2301 -8402, h: 6070.

[7] DFPlayer Mini SKU:DFR:0299. 2017. https://www.dfrobot.com/ wiki/index.php/DFPlayer Mini SK U:DFR0299. Diakses tanggal 12 februari 2017.

[8] PCF8574 i2C Driver Module for LCD Display. 2017. http://telecnatron.com/modules/pc f8574-i2c-Icd-driver/ Diakses tanggal 12 februari 2017.

[9] Arduino. Previous IDE Releases. 2017.https://www.arduino.cc/en/m ain/OIdSoftwareReleases. Diakses tanggal 12 februari 2017.

[10] Agung, Fajri Septia., dkk. Sistem Deteksi Asap Rokok Pada Ruangan Bebas Asap Rokok Dengan Keluaran Suara. 2013. Tesis. Teknik Komputer AMIK GI MDP, Palembang.

[11] Windarto,M.H. Aplikasi Pengatur Lampu Lalulintas Berbasis Arduino Mega 2560 Menggunakan Light Dependent Resistor (LDR) dan Laser. 2012.Arsitron, 3 (2), h: 98-107. 